\title{
BioLink
}

Jurnal Biologi Lingkungan, Industri, Kesehatan

\section{GLANDULAR TRICHOME IN THE ASTERACEAE FAMILY}

\author{
Wina Dyah Puspita Sari*, Cicik Suriani, \& Dina Handayani \\ Department of Biology, Faculty of Mathematics and natural Sciences, Universitas Negeri \\ Medan, Indonesia
}

Submited : 13-01-2020; Reviewed :07-08-2020; Accepted : 15-12-2020

*Corresponding author: E-mail : winadyah@unimed.ac.id

\begin{abstract}
The Asteraceae is a diverse plant species and widely distributed, especially in the tropics and subtropics, consisting of 1,600 - 1,700 genera which include 24,000 - 30,000 species. Asteraceae has characteristics of cup flowers and brackets that are not owned by other plants. The objective of this study was to determine the morphological structure of plants and escpecially the leaf glandular trichome in several species of Asteraceae. The research method used was a descriptive method, to describe and interpret the shape, structure and distribution of leaf trichome in the Asteraceae family. This study used eight species of the Asteraceae family, namely Elephantopus mollis, Bidens pilosa, Tithonia deversifolia, Tridax procumbens, Synedrella nodiflora, Eclipta prostrate, Sphagneticola trilobata and Ageratum conyzoides. The observation results of trichomes at 8 species by Scanning Electrone Microscope (SEM) was obtained varied forms of trichomes, both in shape and size. From the research, it was obtained that the forms of multicellular glandular trichome with various shapes, ranging in size from $50.6 \mu \mathrm{m}-831.9 \mu \mathrm{m}$.
\end{abstract}

Keywords: Asteraceae; Trichome; Plant anatomy

How to Cite: Sari, W.D.P., Suriani, C., \& Handayani, D. (2021). Glandular Trichome In The Asteraceae Family, BioLink: Jurnal Biologi Lingkungan, Industri dan Kesehatan, Vol.7 (2): Hal. 164-171 


\section{INTRODUCTION}

Trichome is hair that grow from epidermal cells with varying shapes, structures and functions. Trichome usually appears on the outer surface of almost all plant organs, both in vegetative organs such as leaves, branches, protective leaves and roots and reproductive organs such as sepals, petals, stamen, gynosium, seeds and fruit (Adedeji et al., 2007; Werker, 2005). Trichome type plays an important role in identifying plant species and understanding the relationships between species). In addition, the special cells found in the epidermis are also needed to complement taxonomic data as the basis for taxonomic and evolutionary studies. Therefore, it is necessary to conduct a research to determine the content description of the shape and size of trichome, especially the Asteraceae family group. Due to the different accumulations and contents, trichome found in various types of plants also have various shapes and sizes.

Trichome in plants also contains the chemicals obtained from glands such as terpenes, phenols and alkaloids, which can function as drugs. Trichome also plays a role in plant defense against insect attack. According to Sari (2010), trichome is one of the plant defense factors in facing the attack of pod activator, Etiella zinckenella, and its density affects the number of eggs of E. zinckenella.
Astercaeae (Compositae) family is a

widely dispersed family group. Asteraceae is a plant whose species are diverse and widely distributed, there are about 24,000 species covered in 1600 genera, which are spread all over the world, except Antarctica (Bayer et al., 2009; Simanjuntak, 2017) The Malesia area has 42 introduced clans and 64 cultivated clans(Steenis, 2008). Asteraceae has the characteristics of cup flowers and brackets that are not shared by other plants. According to Tjitrosoedirdjo (2002), there are 133 species from 74 genera that are in 11 tribes in Sumatra.

The members of this family are mostly herbaceous, sometimes they can be found in the form of shrubs, a little in the form of trees (Bremer \& Anderberg, 1994) (Bremer \& Anderberg, 1994). Many Asteraceae plants have important economic values as decoration, medicinal plants and green vegetables. Many types of this family can be found in Sumatra as grasses and as annoying weeds.

On the surface of the leaves of the family group Asteraceae trichome is commonly found, both on the upper and lower surfaces of the leaves. Glandular trichome that was found in an external position in the epidermis can produce secondary metabolites (Dickison, 2000). The purpose of this study was to determine the diversity of forms of glandular trichomes found in the Asteraceae family. 


\section{MATERIALS AND METHODS}

The research method used descriptive method, to describe the shape and structure of the trichome found in the Asteraceae family. The collected data of the Asteraceae family used as material for research was identification books and plant information pages (The International Plant Name Index / IPNI and Tropicos).

The collection of plants from the Asteraceae family was carried out in the city of Medan and its surroundings. The plant organs taken were fresh leaf organs and fixation was immediately carried out using $10 \%$ Neutral Formalin Buffer solution.To observe trichome, several stages were needed, including the preparation stage and the microscopic observation stage. Initially, the process of cleaning plant samples was carried out at $4^{\circ} \mathrm{C}$. Plant samples were immersed in a caccodylate buffer for about 2 hours, then agitated in a 5 ' "ultrasonic cleaner". The next stage is Prefixation, namely by entering the plant sample into a $2.5 \%$ glutaraldehyde solution for a few hours to 2 days. Furthermore is the fixation stage, by soaking the sample in $2 \%$ tannic acid for 6 hours for a few days, then washing it with $15^{\prime}$ of caccodylate buffer (4 times) and washing it with distilled water for 15 minutes (1 time). Next is the Dehydration stage, namely by immersing plant samples in $50 \%$ alcohol for 5 minutes (4 times), $70 \%$ alcohol for 20 minutes, $85 \%$ alcohol for 20 minutes, $95 \%$ alcohol for 20 minutes (at room temperature), absolute alcohol for 10 minutes ( 2 times). The next is the Drying stage, by soaking in tert butanol for 10 minutes ( 2 times), then frozen in the freezer, then put in the Freezed Drier to dry. Next is the specimen installation stage: glued to the stub specimens according to your needs / wishes, then Coating: coating the specimen with $\mathrm{Au}$ using the ION COATER tool. The preparations were readily observed with a Scanning Electrone Microscope (SEM) to obtain a threedimensional image of the trichomes (Goldstein et al, 1992). Data were observed and described by looking at the shape and size of the trichome.

\section{RESULTS AND DISCUSSION}

From the results of study had been carried out, it was obtained 8 types of plants from the Asteraceae, they are: Elephantopus mollis Kunth., Bidens pilosa L, Tithonia deversifolia (Hemsl.), Tridax procumbens L., Synedrella nodiflora Gaertn, Eclipta prostrata L., Sphagneticola trilobata (L.) Pruski and Ageratum conyzoides L.

From the observation of the 8 types of trichome through Scanning Electrone Microscope (SEM), the trichome image is obtained as shown in Figure 1. 


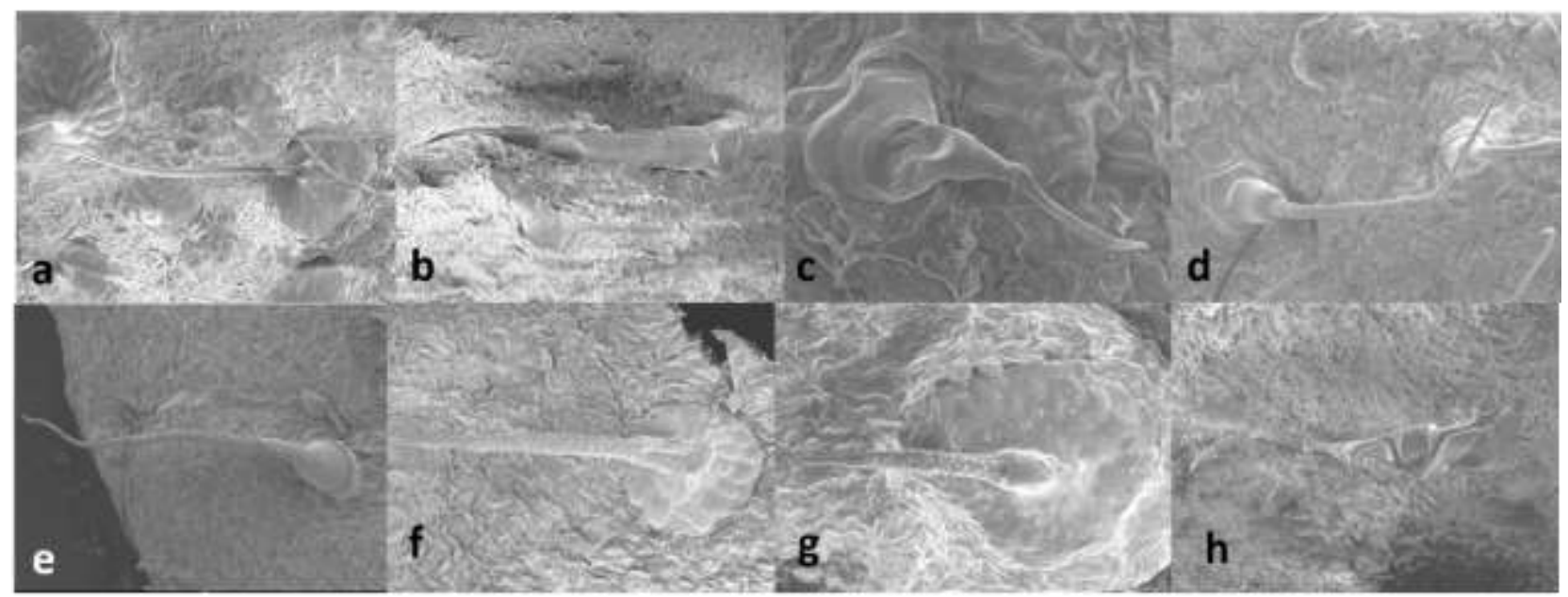

Figure 1. a) Glandular trichoma in Elephantopus mollis Kunth., b) Glandular trichoma in Bidens pilosa L., c) Glandular trichoma in Tithonia diversifolia (Hemsl.), d) Glandular trichoma in Tridax procumbens L., e) Glandular trichoma in Synedrella nodiflora Gaertn ., f) Glandular trichoma in Eclipta prostrata L. g) Glandular trichoma in Sphagneticola trilobata (L.) Pruski., h) Glandular trichoma in Ageratum conyzoides L.

From Figure 1, it can be seen that all types of trichomes found are glandular trichomes which can produce secretion and are shaped like horns. Composed of stem cells and head cells that will release a solution. Glandular trichome has function as to perform the secretion of various compounds such as salt solutions, honey, terpenes, and polysaccharides (Mulyani, 2006). From Dorly et al., (2015) research, some types of asteraceae contain terpenoids, alkaloids, phenols and oils in their trichomes. According to Lipika \& Mukherjee (2012), the trichome-shaped character of the floral and vegetative parts, can be characteristic markers for the Asteraceae family. Perveen et al. (2016), reported 17 species from the Asteraceae family, each of them had a different shape and size of trichome, so that it can be used for classification.
Tridax procumbens $\mathrm{L}$ has the name of Songgolangit area, ketumpang, has a herbal-shaped habitus. The stem is round, the surface of the stem has fine hairy white, the color of the stem is brownish green, the direction of the branch vines. Leaves arranged are opposite crossed, single leaf structure, oval leaf shape, tapered leaf base, tapered leaf tip, and serrated leaf edge. Hairy. The inflorescence is a single knob located at the terminal. Each inflorescence consists of a ribbon flower and a tube flower. Petals of ribbon flowers are white, while tube petals are yellow. The pappus in this plant is coarse hair. In this type, trichome was obtained on the top of the leaf surface. The average length of the plant trichomes ranged from 511.1-675.3 $\mu \mathrm{m}$. The whole body of the trichome has 4 segments with an elongated tapered tip. On the body of the trichome, it is divided into 2 segments. 
Ageratum conyzoides L. or Bandotan is a kind of agricultural weed with herbaceous plantations. The trunk is round, the surface of the trunk is rough and filled with fine hairs, the direction of the stem grows upright, and the color of the stem is yellowish green. Leaves are arranged across each other, single leaf structure, oval leaf shape, pointed leaf tip, rounded leaf base, serrated leaf edge, pinnate leaf bone arrangement, green and yellow leaves. Both leaf surfaces are hairy with glands that lie beneath the leaf surface. The inflorescence was a compound hump. The flowers are located in the terminal and axillary parts. The hump flower in this plant consists of tube flowers only. The tube flower was protected by a collection of protective leaves that sticked together to form a hump by joining into a bouquet. On the protective leaf there are fine hairs. The petal part of the tube flower are purple or white. Pappus in the form of hairs equipped with scales and sticked together. The fruit is black, fine and short hair.

Ageratum conyzoides L. has the form of glandular trichome which are divided into 4 segments. The segment that is located at the bottom (close to the epidermis) has a larger diameter. Getting to the end the tapered. Trichome length for this plant species is $331.8-446.5 \mu \mathrm{m}$. The results obtained from observations using
SEM, did not show optimal results, the trichomes were visibly damaged and wrinkled.

Having several regional names in Indonesia, including ketul, ketul sapi, ketul kebo, ketulan, ajeran, hereuga and lancituwa, Bidens pilosa L. is an herbaceous, commonly found wild as a roadside weed. The stem is round, the surface of the stem is smooth, and the direction of the stem grows upright. Leaves arranged opposite, single leaf structure, lanceolate leaf shape, tapered leaf base, tapered leaf tip, serrated leaf edge, pinnate leaf structure, hairy leaf surface. The inflorescence has a single head. Each inflorescence consists of a ribbon flower and a tube flower. Petals on ribbon flowers are white, while petals on tube flowers are yellow. Flowers are located in the terminal section. Both flowers are protected by a collection of protective leaves which are equipped with fine hair. In the tube and ribbon flowers, black fruit is formed and above it is a pappus with two stiff spines.

In the type of Bidens pilosa L. has glandular trichome consisting of approximately 7 segments. The more the tip, the smaller the diameter of the trichome. The length of the glandular trichomes in Bidens pilosa L. ranged from 50.64-339.4 $\mu \mathrm{m}$.

Eclipta prostrata L. or what is known as urang-aring, has a herbal-shaped 
habitus. Stems grow upright but some are lying and often branched. The round stems are brownish green and hair is slightly coarse. The leaves are arranged across each other, single leaf structure, lanceolate leaf shape, tapered leaf base, tapered leaf tip, almost flat serrated leaf edge, and both hairy and slightly rough leaf surfaces, and pinnate leaves. The inflorescences are single nodes and are located at the terminal and axillary parts. Each inflorescence consists of a ribbon flower and a tube flower. Both of these flowers are protected by protective leaves that stick together. This protective leaf is also equipped with fine hairs. The petals on both flowers are white. This species did not have pappus. The fruit is elongated, flat, hard and hairy. The seeds are needle-shaped and black.

In Eclipta prostrata L. plants, there are trichomes that are 490.3-527.5 $\mu \mathrm{m}$ in length. This type has a warty trichome surface. The lower part of the trichome is visible widening.

With regional names, among others; babadotan, babadotan lalaki, jukit berak kambing, jotang, jotang kuda, jotang lalaki, jotang tai embe, jukut gendreng (Sunda), beruan (Bruwan), Gletangan, Gletang warak, krasuk, legetan, sarunen (Java) (Soerjani et al., 1987), Synedrella nodiflora Gaertn. has a herbal-shaped habitus. The stem is round, the surface of the stem is slightly rough and filled with fine hairs, the direction of growth of the stem is upright, the color of the stem is brownish green. Leaves are arranged opposite crosswise, single leaf structure, oval leaf shape, pointed leaf base, pointed leaf tip, and serrated leaf edge, hairy leaf surface. Inflorescences in the form of a single knob located at the terminal and axillary. Each inflorescence consists of a ribbon flower and a tube flower with white petals. Both of these flowers are covered by phyllaris which is green and covered with fine hair. Both of these flowers had a pappus which was shaped like 2 thorns.

Synedrella nodiflora Gaertn. has the longest glandular trichome size when compared to other observed asteraceae, namely $678.5-831.9 \mu \mathrm{m}$. This plant has trichomes with 3 segments. The first segments (leg cells), which are directly adjacent to the epidermis are oblong in shape. The length of the second segment (body cells) looks longer than the cells of the legs and head cells. The head cells look tapered and the trichomes appear smaller in diameter, when compared to leg cells and body cells.

Tithonia deversifolia (Hemsl.) has a regional name Kipait, flower moon, or paitan, with shrubs. It has a taproot, stems are upright, round, woody, and green. It is a single leaf, alternating, the tip and base is pointed, pinnate and green. The inflorescences are in the form of saucer 
flowers, twig tips, round stalks, tubular petals, downy, green, loose crown, ribbonshaped, smooth, yellow round stamens, yellow curved pistils and yellow. The shape of the fruit is a box fruit, round in shape, when the leaves are young, they are green and when are getting old, they are dark brown. The shape of the seeds is round, hard and brown. Tithonia diversifolia (Hemsl.) has a length of trichomes ranging from 162.9-250.5 $\mu \mathrm{m}$ has 3 segments with a pointed tip.

Sphagneticola trilobata (L.) Pruski, known by another name Wedelia, has a habitus of seasonal herbs (herbs). Stems up to $1 \mathrm{~m}$ long, form angular. The leaves are opposite, with an elongated ovoid shape, the base of the leaves gradually narrows along the stalk and the pointed tip has shallow serrated hairs. (Steenis, 2008). The flowers are compound in the shape of a cup, which has a ribbon flower with a bright yellow crown that forms 1 circle and at the end of the crown is split in 3 and has a tubular flower in the middle with brownish stamens attached to the pistil, the number of them ranges from 20-30 flowers. The flower is located at the end of the flower stalk(Shah et al., 2014).

Sphagneticola trilobata (L.) Pruski. has a broad bottom with less obvious segments. On the surface of the trichome has spikes along the surface. Trichomes of this type are 371.1-423.4 $\mu \mathrm{m}$ in length.
Elephantopus mollis Kunth or forest mustard, is a seasonal herb (herb) with a height of $<1 \mathrm{~m}$, and is found in the form of root rosettes. The leaves are dark green on the upper side and lighter green on the lower surface, and are almost elliptical in shape, the surface of the leaves is hairy. The flowers have protective leaves in pairs and are compound flowers that are tubular flowers like small egrets with 2-3 white colors and are located at the end of the flower stalk. (Shah et al., 2014).

Elephantopus mollis Kunth has glandular trichome which is only one part and is not insulated. At the bottom it looks widened with a pointed trichome tip. These trichomes measure between 477.9$637.1 \mu \mathrm{m}$. Glandular trichome is a type of trichome found in plants that play a role in the secretion of various secondary metabolites. (Juniarni \& Ermayani, 2007) reported that, Artemisia annua, which is a type of the Asteraceae family, has glandular trichomes that can secrete artemisinin, which is an antimalarial bioactive substance.

\section{CONCLUSION}

Trichome observations on 8 species of Astraceae through Scanning Electrone Microscope (SEM) obtained varied forms of trichomes, both shape and size, namely form multicellular glandular trichomes with 
varying shapes, with sizes ranging from

$50.6 \mu \mathrm{m}-831.9 \mu \mathrm{m}$.

\section{ACKNOWLEDGMENT}

The authors would like to thank LPPM

UNIMED for funding this research.

\section{REFERENCES}

Adedeji, O., Ajuwon, O., \& Babawale, O. (2007). Foliar Epidermal Studies, Organograpic Distribution and taxonomic Importance of Trichomes in the Famili Solanaceae. International Journal of Botany, 3(3), 276282.

Bayer, R., Funk, V., Stuessy, T., \& Susanna, A. (2009). Systematics, Evolution, and Biogeography of Compositae. International Association for Plant Taxonomy.

Bremer, K., \& Anderberg, A. A. (1994). Asteraceae: cladistics \& classification. Timber Press.

Dickison, W. C. (200o). Integrative Plant Anatomy. Academic Press.

Dorly, D., Wiryo, B. A., Nurfaizah, I., \& Nidyasari, R. S. (2015). Secretory Structure and Histochemistry Tests of Asteraceae Family Members of Medicinal Plants in Walat Mountain Educational Forest. Jurnal.Uns.Ac.Id, 667-673. https://jurnal.uns.ac.id/prosbi/article/view/ 7044

Goldstein, J. I., Newbury, D. E., Echlin, P., Joy, D. C., Romig, A. D., Lymna, C. E., Fiori, C., \& Lifshin, E. (1992). Scanning Electron Microscopy and X-ray Microanalysis; A Text for Biologist, Materials Scientist, and Cytologist. Second edition (Second Edi). Plemun Press.
Juniarni, \& Ermayani, T. M. (2007). Penentuan Waktu Matang Fisiologi Trikoma Kelenjar Artemisia annua L. dalam Hubungannya dengan Produksi Artemisinin. Institut Pertanian Bogor.

Lipika, S., \& Mukherjee, S. K. (2012). Morphological variation of trichomes in some common species of Asteraceae. International Journal of Pharmaceutical Research and Bio-Science, 1(6), 408-425.

Mulyani, S. (2006). Anatomi Tumbuhan. Kanisius.

Perveen, A., Khan, M., Mansuri, S., \& Tabassum, T. (2016). Morphological studies on trichome of family Asteraceae. International Journal of Biology and Biotechnology, 13, 177-182.

Sari, K. P. (2010). Trikoma Sebagai Faktor Ketahanan Kedelai Terhadap Hama Penggerek Polong. Buletin Palawija, 20, 8083.

http://ejurnal.litbang.pertanian.go.id/index. php/bulpa/article/view/1753

Simanjutak, H.A., (2017). Potensi Famili Asteraceae Sebagai Obat Tradisional Di Masyarakat Etnis Simalungun Kabupaten Simalungun Provinsi Sumatera Utara, BioLink, Vol. 4 (1) Hal. 11-18

Soerjani, M., Koestermans, A. J. G. H., \& Tjitrosoepomo, G. (1987). Weeds of Rice in Indonesia. Balai Pustaka.

Steenis, V. (2008). Flora. PT. Pradnya Paramita.

Syah, A. S., Sulaeman, S. M., \& Pitopang, R. (2014). Jenis-Jenis Tumbuhan Suku Asteraceae di Desa Mataue Kawasan Taman Nasional Lore Lindu. Online Journal of Natural Science, 3(3), 297-312.

Tjitrosoedirdjo, S. S. (2002). Notes on the Asteraceae of Sumatera. BIOTROPIA-The Southeast Asian Journal of Tropical Biology, $19,65-84$

Werker, E. (2005). Trichome diversity and development in plant trichomes. Advances in Botanical Research, 31. 